Research Article

\title{
Structure, Reproductive Biology, and Regeneration Status of Podocarpus falcatus (Thunb.) R. B. ex Mirb. in Bale Mountains, Southern Ethiopia
}

\author{
Mesfin Woldearegay ${ }^{1}{ }^{1}$ and Tamrat Bekele ${ }^{2}$ \\ ${ }^{1}$ Department of Biology, College of Natural and Computational Sciences, Debre Berhan University, \\ P.O. Box 445, Debre Berhan, Ethiopia \\ ${ }^{2}$ Department of Plant Biology and Biodiversity Management, Addis Ababa University, P.O. Box 3434, Addis Ababa, Ethiopia
}

Correspondence should be addressed to Mesfin Woldearegay; mesfinwa@gmail.com

Received 20 May 2020; Revised 25 September 2020; Accepted 30 September 2020; Published 23 October 2020

Academic Editor: Ahmad A. Omar

Copyright $\odot 2020$ Mesfin Woldearegay and Tamrat Bekele. This is an open access article distributed under the Creative Commons Attribution License, which permits unrestricted use, distribution, and reproduction in any medium, provided the original work is properly cited.

\begin{abstract}
This study was carried out in the Dodola forest, Southern Ethiopia, to investigate the structure, reproductive biology, and regeneration status of Podocarpus falcatus. Based on their disturbance status, two blocks each having an area of 16 ha $(400 \mathrm{~m} \times 400 \mathrm{~m})$ were laid in the forest to collect vegetation data. 16 plots $(100 \mathrm{~m} \times 100 \mathrm{~m})$ and 256 subplots $(25 \mathrm{~m} \times 25 \mathrm{~m})$ were established in each block. The population status of Podocarpus falcatus $(\mathrm{dbh} \geq 5 \mathrm{~cm})$ was assessed in the 256 subplots. The regeneration status of Podocarpus falcatus was also assessed around 40 randomly selected female trees isolated at least $10 \mathrm{~m}$ from any other female tree in each block. A total of 1363 Podocarpus falcatus individuals were recorded, with an average distribution of 43 individuals $\mathrm{ha}^{-1}$ and a higher proportion of small-sized individuals. The population structures of Podocarpus falcatus in the two blocks were a typical inverted J-shape pattern, indicating good regeneration and recruitment status of the study species. Podocarpus falcatus had a good regeneration status in Dodola forest and also larger quantities of its seedlings were recorded under canopy shades suggesting that the species is shade tolerant. The density of seedlings and saplings was small within $4 \mathrm{~m}$ radius from the seed source (female trees) compared to that observed greater than $4 \mathrm{~m}$ distance. Thus, poor regeneration is observed within a $4 \mathrm{~m}$ radius around the female trees compared to distances greater than $4 \mathrm{~m}$. Therefore, the local community and other responsible stakeholders should work together to stop and/or reduce the selective cutting of this ecologically and economically important tree species in the forest.
\end{abstract}

\section{Introduction}

Biodiversity refers to the variability among living organisms from all sources including terrestrial, marine, and other aquatic ecosystems. It is not only the variety of plant and animal species but also the variety of genes within those species and the variety of ecosystems in which the species inhabit [1]. Biodiversity is important for the functioning of the ecosystem on which humans depend for a variety of goods and services. However, there has been a rapid decline in the biodiversity of the world mainly due to habitat destruction and fragmentation, overharvesting, pollution, invasive species, and unsustainable practices in agriculture, aquaculture, and forestry $[2,3]$. In many tropical areas of the world, for example, deforestation is still increasing, and habitats of all types, including forests, grasslands, and wetlands, continue to be fragmented and degraded [4]. The disappearance of species can result in the loss of wild relatives of domesticated crop species and the genes we use to improve agricultural resilience and the production of a wide range of ecosystem services that support humans and all life on Earth $[4,5]$. Thus, strategies to overcome such losses must therefore be sought in the larger policy framework of development.

Ethiopia, located in the Horn of Africa, has been endowed with diverse fauna and flora that makes it an important regional center of biological diversity and 
endemism $[6,7]$. This is mainly because the country possesses greatly varying landscapes ranging from high and rugged mountains, flat-topped plateaus, deep gorges, and incised rivers and rolling plains [8-10] that have made the country have diverse ecological conditions, which in turn contributed to its diverse biological resources with endemic elements [7]. The flora of Ethiopia is very heterogeneous and it is estimated to contain around 6,000 species of higher plants, of which about $10 \%$ are endemic $[11,12]$. Many of the genetic resources of the country remain unexplored and biodiversity resources are under continuous threats of destruction mainly due to habitat loss and fragmentation, unsustainable utilization of biological resources, agricultural expansion, invasive species, climate change, and pollution $[10,13]$. Ethiopian forest resource is declining over time [14]. For example, the rate of deforestation accelerated towards the beginning of the twentieth century and about $16 \%$ of the land area was estimated to have been covered by high forests in the early 1950s which declined to $3.6 \%$ in the early 1980 s and further down to $2.7 \%$ in 1989 [8]. According to FAO's report [14], the rate of deforestation in the country was 141,000 ha per year and this extensive amount of habitat loss or destruction may have resulted in a rapid dwindling of the genetic resources of the country [10].

Podocarpus falcatus is one of the characteristic tree species in the Dry Afromontane forests of Ethiopia [15]. It is a relatively tall evergreen tree with a height of about $30(-35)$ $\mathrm{m}$ [16] and a diameter of about 57 to $92 \mathrm{~cm}$ [17]. The wood is soft and its colour ranges from yellowish white to pale brown [17]. Podocarpus falcatus is an extremely valuable tree both ecologically and economically. Ecologically, its massive evergreen plant body, as well as the dense crown, can protect the soil from storms and erosive rainfall, which are frequent on where the species occurs. As a result, forests largely composed of Podocarpus falcatus trees contribute greatly to the formation of cool and clear springs as well as to the formation of suitable habitats, even during the driest and hottest seasons of the year $[17,18]$. Besides, the fleshy fruits of the tree are a source of food for many birds and mammals such as bats and the rare colobus monkey (Colobus polykomos) $[17,19]$ as well as the large dense crown of the tree is often a roosting and nesting site for various birds. Economically, the attractive yellowish-white wood of Podocarpus falcatus yields an excellent timber for manufacturing different wood products (Dale and Greenway, 1961; cited in $[18,20])$. The timber is also used for flooring and roofing. The bark contains 3-6\% tannin and is used for tanning leather, and the oil extracted from the seeds is used for medicinal purposes [21].

The high demand for its best-quality timber and fire wood has exposed the species to overexploitation, both legally and illegally, to the extent that its populations have been reduced below the level of perpetuating themselves and disappeared from many of their natural habitats $[17,18]$. Thus, information on the population structure, reproductive biology, and regeneration status of Podocarpus falcatus will have paramount importance for the conservation and sustainable utilization of the species. Therefore, the objective of this study was to (a) Characterize and evaluate the population structure, regeneration status, and reproductive biology of Podocarpus falcatus in Southern Ethiopia.

\section{Materials and Methods}

2.1. Study Area. The study was conducted in Dodola district which lies between latitudes $6^{\circ} 56^{\prime} \mathrm{N}$ and $7^{\circ} 01^{\prime} \mathrm{N}$ and longitude $39^{\circ} 11^{\prime} \mathrm{E}$ and $39^{\circ} 16^{\prime} \mathrm{E}$ (Figure 1), situated within the Bale Mountains massif. The Bale Mountains massif constitutes the largest portion of the southeastern highlands of Ethiopia. The northern slopes of the mountains, which also include the Dodola forest, are occupied by dry Afromontane forests $[16,22]$. The area has a mean annual temperature of $19.1^{\circ} \mathrm{C}$ and a mean annual rainfall of $782.8 \mathrm{~mm}$.

\subsection{Reproductive Biology of Podocarpus falcatus.} Podocarpus falcatus is a dioecious plant, where the male and female reproductive structures are found on separate individuals. The male cones are borne on small pedicles, which usually occur in pairs or triplets in the axils of foliage leaves. However, they may also occur singly. The female cones are composed of the epimatium (the fleshy outer covering of the fruit) and sclerotesta (the hard covering of the seed). They are axillary and occur at the distal ends of a vegetative shoot. They are green when not ripe and become yellowish when ripe [17]. Pollination is mainly carried out by wind. The capacity of the species for fruit production and seed fertility is very low due to frequent cultivation of land under tree canopies and the practice of tree lopping [23]. Thus, investigation of the species regeneration status around female trees helps to understand the reproduction process.

2.3. Sampling Design and Data Collection. A reconnaissance survey was made across the forest to collect information on site conditions, disturbance status of the forest, and selection of sampling sites. Following this, two sampling blocks, each having an area of $16 \mathrm{ha}(400 \mathrm{~m} \times 400 \mathrm{~m})$, were laid in the forest for population assessment following Yoshikura [24]. The two blocks were selected based on their level of disturbance. The type and extent of the anthropogenic disturbance were visually estimated for each block following Senbeta et al. [25]. The magnitude of disturbance was rated from 0 to 3 based on visible signs of disturbance such as livestock grazing and trampling, fire, tree stumps (tree cutting), and firewood collection. The values of disturbance were fixed as follows: 0: no disturbance; 1: if anyone of the above-mentioned factors is present; 2: if any two of the above-mentioned factors are present; and 3: if all of the above-mentioned factors are present. Block I was located at the foot of the mountain while block II was located in the middle of the forest. Each block consisted of 16 plots $(100 \mathrm{~m} \times 100 \mathrm{~m})$ and 256 subplots $(25 \mathrm{~m} \times 25 \mathrm{~m})$ as shown in Figure 2. Data were collected in all 256 subplots.

In each block, all female trees isolated $10 \mathrm{~m}$ from any other female tree were first identified and the stem was tied by red ribbon where a serial number and plot number were written on it. Forty female trees were randomly selected from 


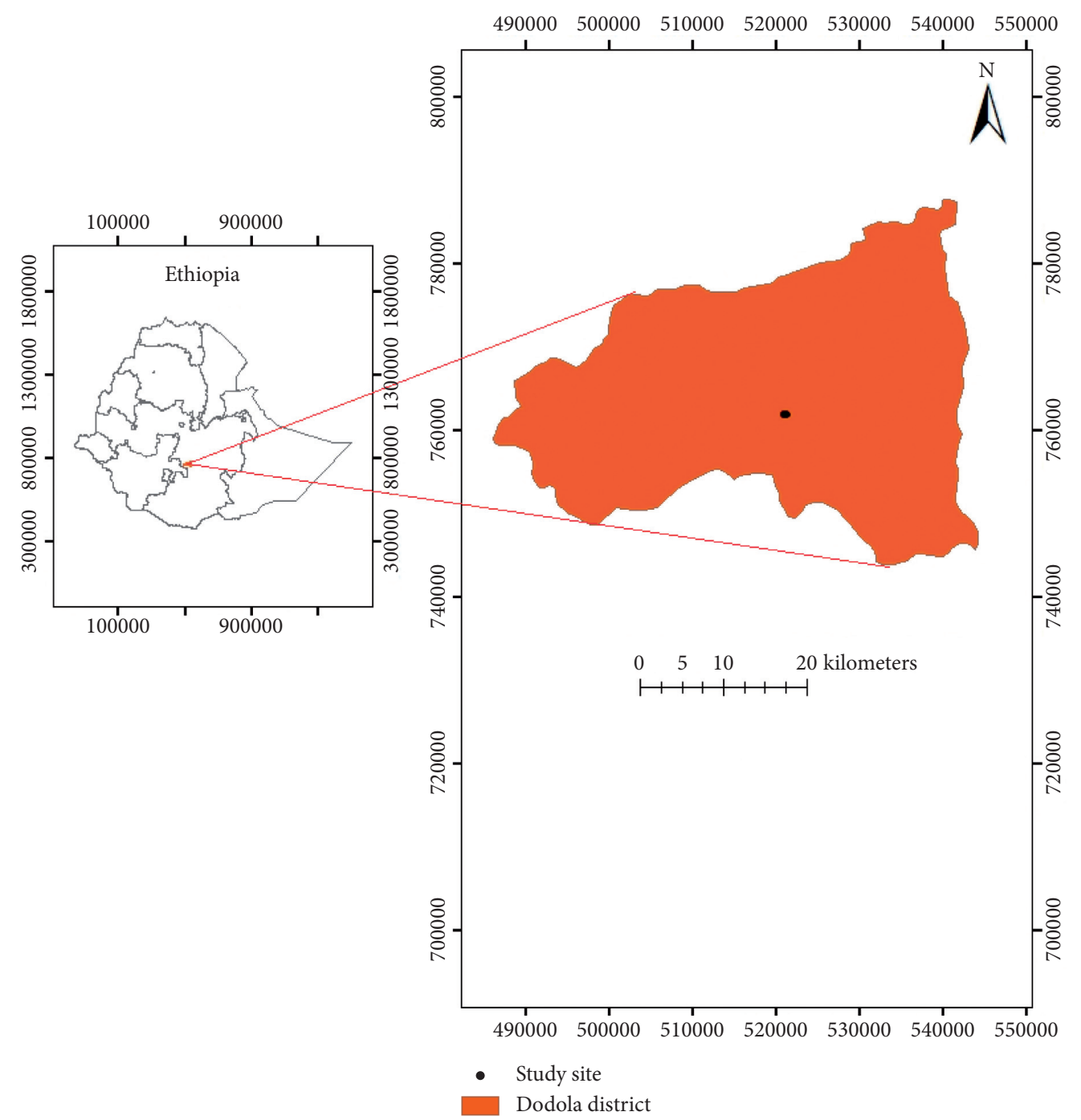

FIgURE 1: Location map of the study area.

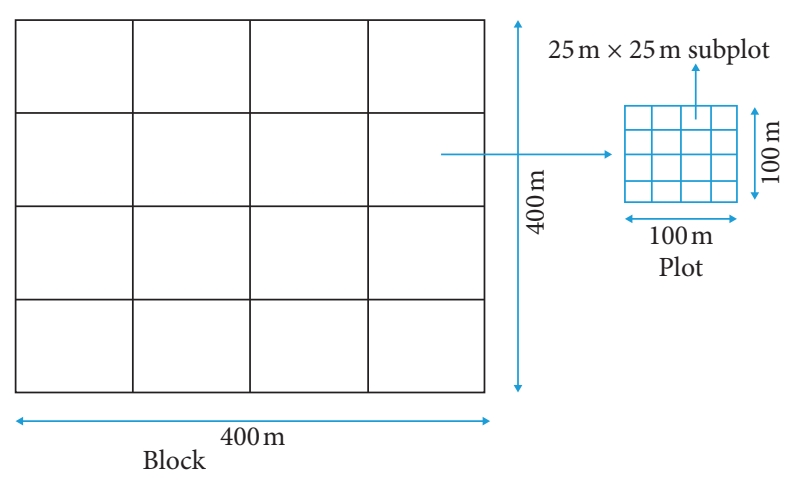

FIgURE 2: Sampling design for population assessment of $P$. falcatus in Dodola forest.

the serial numbers by using a lottery system and two subplots were laid around each female tree. The first subplot (B-1) was a $4 \mathrm{~m}$ radius circle (area $=50.2 \mathrm{~m}^{2}$ ) around a mature female tree and the second subplot (B-2) was $36^{\circ}$ around and 4-20 m away from the female tree $\left(121 \mathrm{~m}^{2}\right)$ (Figure 3 ).

2.4. Vegetation Data Collection. In each square sampling subplot (Figure 2), all Podocarpus falcatus individuals $\geq 5 \mathrm{~cm}$ diameter at breast height ( $\mathrm{dbh}$ ) were counted. The diameter was measured for every individual tree having $\mathrm{dbh} \geq 5 \mathrm{~cm}$ using a diameter tape. If a tree branched at breast height or below, the diameter was measured separately for the branches and the average was taken. Height was measured for every individual tree with $\mathrm{dbh} \geq 5 \mathrm{~cm}$ using a $15 \mathrm{~m}$ long measuring pole and hypsometer. In cases where the tree was too tall and where topography and/or crown structure made it difficult to use hypsometer, the height of the tree was visually estimated.

In each circular and angled subplot (Figure 3), seedlings (plants with heights $\geq 10 \mathrm{~cm} \leq 150 \mathrm{~cm}$ and $\mathrm{dbh}<5 \mathrm{~cm}$ ) and saplings (plants with heights $>150 \mathrm{~cm}$ and $\mathrm{dbh}<5 \mathrm{~cm}$ ) [26] were counted. Each subplot was classified into two 


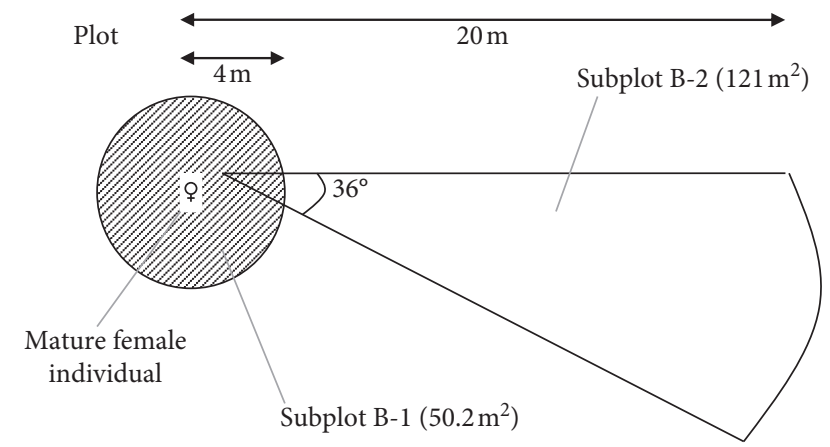

FIgURE 3: Sampling units for regeneration assessment around female trees in Dodola forest.

categories: open areas and shaded areas. Seedlings, which had reached $10 \mathrm{~cm}$ in height, were considered to be established and likely to persist.

2.5. Identification of Tree Sex. Determination of sex of Podocarpus falcatus trees as female, male, and unrecognizable sex was carried out based on biological methods. The identification of female trees was easier than males because the fruits persist in the branchlets or on the ground under the female trees for a long time. On the other hand, identification of male trees was relatively difficult. This is mainly because the male cones were very small and difficult to detect easily on the branchlets or the ground under the trees. Sometimes in cases where the trees were too tall and difficult to see the fruits or cones in their branchlets or where no fruits or cones were found on the ground, the trees were identified as unrecognizable sex.

2.6. Data Analysis. Population structure analysis of Podocarpus falcatus trees $\geq 5 \mathrm{~cm}$ dbh was based on density, dbh, and height [27]. Density was computed by converting the count from all sample plots into a hectare basis [28]. Height and diameter at breast height were randomly classified into 9 and 11 classes, respectively, and the density distributions of trees in each class were computed for each block. The number of $P$. falcatus populations in the two blocks was compared based on their mean tree number and mean tree size (dbh). Significant differences between the two blocks were detected by using a T-test following Sokal and Rohlf [29].

The sex ratio (female to male) was calculated for each block in various dbh classes and then statistically tested (chi-square) for variation from the theoretical sex ratio (1: 1). In this test, diameter at breast height was classified into 9 classes and trees $>20 \mathrm{~cm}$ dbh were used to avoid the problem of sex identification in small dbh classes since sex determination is very difficult in smaller individuals.

The density of seedlings and saplings of Podocarpus falcatus and percent canopy cover of each subplot by the forest canopy was computed and compared between the two blocks. The density of seedlings and saplings within specified distances from the seed source (female tree) was also compared.

\section{Results}

\subsection{Population Structure}

3.1.1. Abundance and Density of Trees. A total of 1363 of Podocarpus falcatus trees were recorded in the two study blocks. The two blocks did not significantly differ in their mean number of Podocarpus falcatus trees (Table 1). The lowest number of individuals $\mathrm{ha}^{-1}$ was 21 for block I and 19 for block II. The highest number of individuals ha ${ }^{-1}$ was 89 for block I and 66 for block II. The mean dbh values of the two blocks did not differ significantly. The mean dbh value in block I was 36.6 and the mean dbh value in block II was 45.9 (Table 1). The lowest and the highest mean dbh value per hectare was 16.2 and $87.6 \mathrm{~cm}$ in block I and 22.5 and $74.1 \mathrm{~cm}$ in block II.

The density of Podocarpus falcatus trees with $\mathrm{dbh} \geq 5 \mathrm{~cm}$ was 43 individuals $\mathrm{ha}^{-1}$ in Dodola forest. The density of Podocarpus falcatus trees with $\mathrm{dbh}>10 \mathrm{~cm}$ was 26.5 individuals $\mathrm{ha}^{-1}$ and those with $\mathrm{dbh}>20 \mathrm{~cm}$ were 17.44 individuals $\mathrm{ha}^{-1}$. This ratio for Podocarpus falcatus in the Dodola forest was 1.5 (Table 2).

3.2. Diameter at Breast Height. The density distribution of Podocarpus falcatus individuals in the various dbh classes decreased continuously in the number of individuals towards the higher dbh classes. As dbh classes increased, the number of individuals decreased with some irregularities in block II. The distribution of individuals in the two blocks indicated a reversed J-shape population structure (Figure 4).

A larger proportion of Podocarpus falcatus individuals were found in the first two dbh classes $(5-10 \mathrm{~cm}$ and $11-20 \mathrm{~cm}$ ) in the two blocks (i.e., 65 and 53\% in blocks I and II, resp.). The proportion of individuals with a dbh of $>180 \mathrm{~cm}$ was larger in block II (1.9\%) than in block I (1.2\%). The largest Podocarpus falcatus tree was found in block II with a dbh of $237.3 \mathrm{~cm}$.

3.3. Height. The height class distribution of Podocarpus falcatus individuals showed that the number is decreasing with increasing height in Dodola forest. That is, a higher number of individuals were found at the seedling stage and gradually decreasing towards sapling and mature trees. The distribution pattern showed a continuous representation of individuals in all height classes in the two blocks (Figure 5).

3.4. Sex Ratio. The total sex ratio of females to males was 1.06 and 0.94 in blocks I and II, respectively, which did not deviate significantly from the theoretical ratio of 1.0 (Table 3). Both sexes were equally frequent in the samples taken in the two blocks. However, a significant variation was observed in the dbh classes between 101 and $120 \mathrm{~cm}$ and $\mathrm{dbh}$ $>180 \mathrm{~cm}$ in block II (Table 3 ). 
TABLE 1: $T$-test for population characteristics of $P$. falcatus individuals $\geq 5 \mathrm{~cm}$ in the two blocks.

\begin{tabular}{|c|c|c|c|c|}
\hline Population characteristics & Block I (mean) & Block II (mean) & Block I vs. block II $t$-values & Differences \\
\hline Total number of trees & $42.4 \pm 11.8$ & $42.8 \pm 7.1$ & -0.06 & NS \\
\hline Tree size dbh $(\mathrm{cm})$ & $36.6 \pm 8.8$ & $45.9 \pm 8.8$ & -1.59 & NS \\
\hline
\end{tabular}

NS: not significant at $5 \%$ confidence level.

Table 2: Tree density comparison of Dodola, Magada, and Manna Angetu forests.

\begin{tabular}{lccc}
\hline Forests & $a$ & $b$ & $a / b$ \\
\hline Dodola $^{\mathrm{a}}$ & 26.5 & 17.44 & 1.5 \\
Magada $^{\mathrm{M}}$ & 28 & 26.72 & 1.0 \\
Manna Angetu $^{\mathrm{b}}$ & 18.52 & 13.17 & 1.4 \\
\hline
\end{tabular}

Source: a [24]; b [30].Note: $a=$ for trees $>10 \mathrm{~cm} \mathrm{dbh;} b=$ for trees $>20 \mathrm{~cm} \mathrm{dbh;} \mathrm{and} a / b=$ ratio.

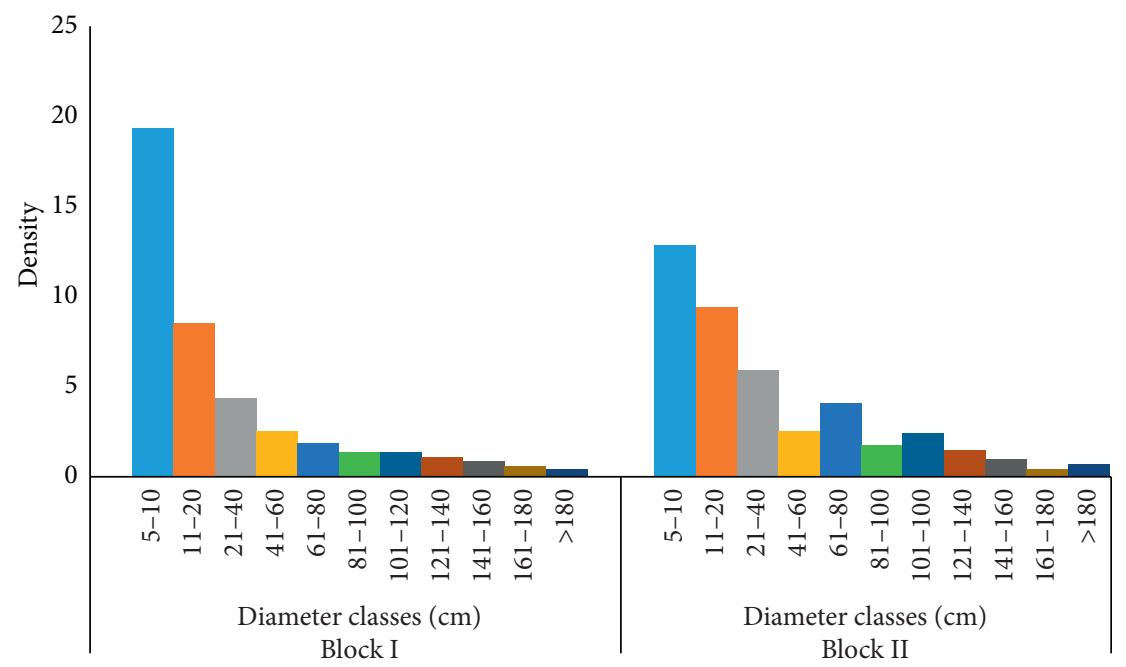

Figure 4: Density distribution of P. falcatus individuals in diameter classes in the two blocks in Dodola forest.

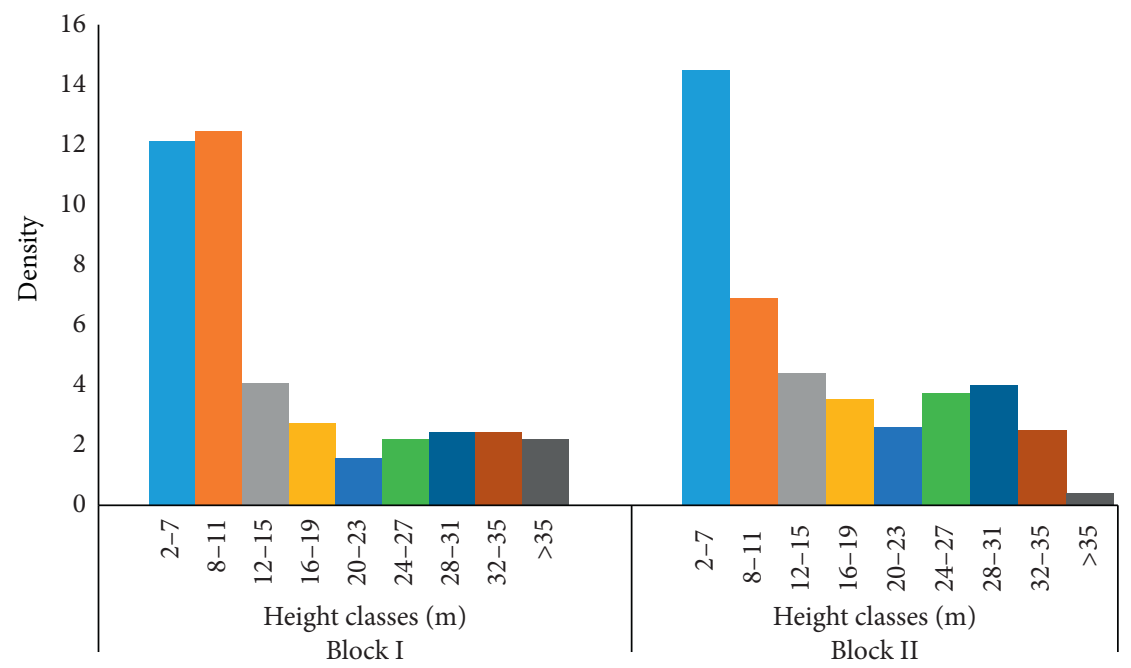

FIgUre 5: Height distribution of P. falcatus in height classes in the two blocks in Dodola forest. 
TABLe 3: The number of females, males, and sex ratio of $P$. falcatus individuals in diameter classes $(>20 \mathrm{~cm} \mathrm{dbh})$ in the two blocks in Dodola forest.

\begin{tabular}{lcccc}
\hline $\begin{array}{l}\text { DBH classes } \\
(\mathrm{cm})\end{array}$ & Females & Males & $\begin{array}{c}\text { Sex ratio (female: } \\
\text { male) }\end{array}$ & $\begin{array}{c}\text { Chi- } \\
\text { square }\end{array}$ \\
\hline $\begin{array}{lccc}\text { (a) Block } \\
21-40\end{array}$ & 11 & 10 & 1.10 & $0.05^{\mathrm{NS}}$ \\
$41-60$ & 14 & 22 & 0.64 & $1.78^{\mathrm{NS}}$ \\
$61-80$ & 15 & 15 & 1.00 & $0.00^{\mathrm{NS}}$ \\
$81-100$ & 11 & 11 & 1.00 & $0.00^{\mathrm{NS}}$ \\
$101-120$ & 11 & 12 & 0.92 & $0.04^{\mathrm{NS}}$ \\
$121-140$ & 12 & 6 & 2.00 & $2.00^{\mathrm{NS}}$ \\
$141-160$ & 9 & 5 & 1.80 & $1.14^{\mathrm{NS}}$ \\
$161-180$ & 6 & 3 & 2.00 & $1.00^{\mathrm{NS}}$ \\
$>180$ & 4 & 4 & 1.00 & $0.00^{\mathrm{NS}}$ \\
Total & 93 & 88 & 1.06 & $0.14^{\mathrm{NS}}$ \\
\hline (b) Block II & & & & \\
$21-40$ & 8 & 3 & 2.67 & $2.27^{\mathrm{NS}}$ \\
$41-60$ & 11 & 13 & 0.85 & $0.17^{\mathrm{NS}}$ \\
$61-80$ & 25 & 38 & 0.66 & $2.68^{\mathrm{NS}}$ \\
$81-100$ & 14 & 13 & 1.08 & $0.04^{\mathrm{NS}}$ \\
$101-120$ & 11 & 27 & 0.41 & $6.74^{*}$ \\
$121-140$ & 13 & 11 & 1.18 & $0.17^{\mathrm{NS}}$ \\
$141-160$ & 10 & 5 & 2.00 & $1.67^{\mathrm{NS}}$ \\
$161-180$ & 5 & 2 & 2.50 & $1.29^{\mathrm{NS}}$ \\
$>180$ & 10 & 2 & 5.00 & $5.33^{*}$ \\
Total & 107 & 114 & 0.94 & $0.22^{\mathrm{NS}}$ \\
\hline
\end{tabular}

NS: not significant; ${ }^{*}$ significant, $P<0.05$.

\subsection{Regeneration Assessment}

3.5.1. Density of Seedlings and Saplings. The total seedling density was 27 individuals $\mathrm{ha}^{-1}$ in block I and 21 individuals $\mathrm{ha}^{-1}$ in block II while the total sapling density was 6 individuals $\mathrm{ha}^{-1}$ in block I and 9 individuals $\mathrm{ha}^{-1}$ in block II (Table 4). The number of seedlings and saplings observed within $4 \mathrm{~m}$ distance from the seed source (female tree) was small compared with that observed over longer distances in the two blocks (Table 4). Thus, poor regeneration is observed within a $4 \mathrm{~m}$ radius around the female trees compared to distances greater than $4 \mathrm{~m}$.

Higher proportions of seedlings $(90.8 \%$ in block I and $68 \%$ in block II) and saplings ( $77.1 \%$ in block I and $67 \%$ in block II) were recorded under canopy shades than seedlings (9.2\% in block I and 32\% in block II) and saplings (22.9\% in block I and 33\% in block II) in open areas (Table 5).

\section{Discussion}

In Dodola forest, the mean number of Podocarpus falcatus trees $\geq 5 \mathrm{~cm}$ dbh did not show significant variation in the two blocks. In block I, most $P$. falcatus individuals had a dbh value of less than $40 \mathrm{~cm}$ indicating a population in which younger trees predominated. Conversely, in block II, most values were above $40 \mathrm{~cm}$ dbh indicating a population in which larger trees predominated. This indicates that block I was heavily disturbed than block II. The abundance of Podocarpus falcatus trees $\geq 5 \mathrm{~cm}$ dbh was relatively higher than Magada forest. Yoshikura [24] reported 927 individuals of Podocarpus falcatus in Magada forest, located in Southern Ethiopia, as compared to 1363 individuals by this study, in Dodola forest. This might be attributed to the differences in the management practices of the two forests. Dodola forest is well managed by the integrated forest management project (IFMP) established in collaboration with the local people than Magada forest which is highly affected by anthropogenic disturbances and livestock grazing [24, 31].

The density of Podocarpus falcatus trees was very low (43 individuals $\mathrm{ha}^{-1}$ ) when compared with some other Afromontane forests like Wof Washa (105 individuals ha ${ }^{-1}$ ) [32], Chilimo (120 individuals ha ${ }^{-1}$ ) [33], Dense (82 individuals $\mathrm{ha}^{-1}$ ) [34], Biteyu (63 individuals $\mathrm{ha}^{-1}$ ) [35], Tiro Boter Becho (105 individuals ha ${ }^{-1}$ ) [36], and Chato (115 individuals $\mathrm{ha}^{-1}$ ) [37] forests but higher than that reported for Magada forest (29 individuals ha ${ }^{-1}$ ) [24] and Southern cape forests (10 individuals $\mathrm{ha}^{-1}$ ) [19]. Variations in density distributions could be attributed to differences in topographic gradients and habitat preferences of species forming the forest and the degree of anthropogenic influences [38]. The ratio of density of Podocarpus falcatus individuals with $\mathrm{DBH}>10 \mathrm{~cm}$ to $\mathrm{DBH}>20 \mathrm{~cm}$ in Dodola forest (1.5) was found to be higher than that of some other Afromontane forests such as Magada (1.0) [24] and Manna Angetu (1.4) [30], indicating a higher predominance of small-sized individuals in Dodola forest than the forests compared. This indicates that the study species could have been affected by anthropogenic disturbance as revealed by the absence of large-sized individuals. According to Grubb et al. [39], lower values for the ratio of small-sized individuals to large-sized individuals could be indicators of forests which developed under natural conditions and with minimum disturbances, while higher values indicate a predominance of small-sized individuals that start to grow following excessive cuttings or other anthropogenic disturbances.

The results on the overall distribution of Podocarpus falcatus trees in Dodola forest across $11 \mathrm{dbh}$ classes indicate an inverted J-shape distribution except for slight irregularities in block II. An inverted J-shape distribution is a general pattern of normal population structure where the species had the highest number of individuals at lower $\mathrm{dbh}$ classes with a gradual decrease towards the higher dbh classes. Such inverted J-shape distributions across dbh classes are indicative of an overall healthy regenerating forest [40]. A similar pattern of population structure was reported in previous works from different Afromontane forests of Ethiopia (e.g., [41-45]). The population structure of $P$. falcatus indicates selective removal of individuals especially in the diameter classes between 41 to $60 \mathrm{~cm}$ and 81 to $100 \mathrm{~cm}$ in block II. This might be attributed to the selective cutting of individuals of preferred sizes by the local people for different purposes such as construction, lumbering, and other domestic uses. Selective logging which involved cutting of preferred individuals from a stand without due consideration of their future regeneration has led to the depletion of mature trees in Harenna forest [46]. Ahmed et al. [47] also concluded that gaps in size class structure were due to cutting rather than due to the failure of regeneration in their study in Pakistan. 
TABLE 4: Total number of seedlings and saplings, distances from female tree (m), and density of $P$. falcatus individuals in the two blocks in Dodola forest.

\begin{tabular}{|c|c|c|c|c|c|c|}
\hline \multicolumn{7}{|c|}{ Distances from female } \\
\hline \multirow{2}{*}{ Block } & \multirow{2}{*}{ Seedlings/saplings } & \multicolumn{3}{|c|}{ Tree $(\mathrm{m})$} & \multirow{2}{*}{ Total } & \multirow{2}{*}{ Density (indiv. ha ${ }^{-1}$ ) } \\
\hline & & $0-4$ & $4-20$ & $>20$ & & \\
\hline \multirow{2}{*}{ I } & Seedlings & 56 & 257 & 120 & 433 & 27 \\
\hline & Saplings & 4 & 80 & 12 & 96 & 6 \\
\hline \multirow{2}{*}{ II } & Seedlings & 23 & 223 & 88 & 334 & 21 \\
\hline & Saplings & 8 & 107 & 30 & 145 & 9 \\
\hline
\end{tabular}

TABLE 5: Seedlings and saplings of $P$. falcatus under canopy shades and in open areas.

\begin{tabular}{|c|c|c|c|c|}
\hline \multirow{2}{*}{ Block } & \multicolumn{2}{|c|}{ Number of seedlings } & \multicolumn{2}{|c|}{ Number of saplings } \\
\hline & Canopy shades & Open areas & Canopy shades & Open areas \\
\hline I & 90.8 & 9.2 & 77.1 & 22.9 \\
\hline II & 68 & 32 & 67 & 33 \\
\hline
\end{tabular}

Figures are \% values within each block in Dodola forest.

More than half of the Podocarpus falcatus individuals in the two blocks (i.e., 65 and $53 \%$ in block I and II, resp.) were found in the lowest dbh classes $(5-10 \mathrm{~cm}$ and $11-20 \mathrm{~cm})$. The presence of a large number of small- to medium-sized individuals and the relatively small proportion of large-sized trees indicates that Dodola forest is in a stage of secondary development. According to Aye et al. [48], the presence of higher tree density in small dbh classes compared to large $\mathrm{dbh}$ classes is a secondary forest characteristic. Bekele [49] also related the abundance of small individuals $(\mathrm{dbh}<20 \mathrm{~cm})$ in four dry Afromontane forests of Ethiopia to the history of the forests and their stage of development. The distribution of $P$. falcatus individuals in the different height classes decreased with increasing height classes showing an inverted J-shape pattern of distribution. This continuous height class distribution with an inverted J-shape curve implies healthy regeneration of the species [50-52].

The total sex ratio of Podocarpus falcatus trees in Dodola forest was found to be proportional (i.e., one female to one male tree). However, significant variation was observed in block II due to a higher number of male and female individuals in the dbh class $101-120$ and $>180$, respectively. This could be attributed to the problem of sex identification. Since trees in these dbh classes were very tall, sex determination was difficult especially for male trees as the male cones are too small to be detected in the branchlets of tall trees. The presence of an equal proportion of female and male Podocarpus falcatus individuals in the forest may increase the chance of performing effective cross-pollination that leads to better production of seeds. Most of the seeds of Podocarpus falcatus are predetermined to germinate readily after they are dispersed to produce seedlings on the forest floor, the "seedling bank" [53]. Probably, this could be one of the reasons for the better regeneration status of the species in the forest as the formation of seedling banks under the forest canopy is the major natural regeneration route of the species [54].
The regeneration status of tree species in any forest is determined by the recruitment of seedlings and saplings $[55,56]$. The regeneration of Podocarpus falcatus in the forest exhibited a higher number of individuals at the seedling stage. This relatively higher seedling population indicates good recruitment that could be attributed to reduced human activities and the dominance of mature trees of the species. Compared with other dry Afromontane forests such as Gelawdios $\left(9 \mathrm{ha}^{-1}\right)$ [57] and Zegie $\left(6 \mathrm{ha}^{-1}\right)$ [58], Podocarpus falcatus had relatively higher seedling density in Dodola forest. This suggests the ecological suitability of the forest for Podocarpus to exhibit its potential for higher seedling recruitment and healthy regeneration. This finding agrees well with the results reported from previous work on the species $[46,59]$. However, the lower number of individuals at the sapling stage might be due to the felling of trees in the forest that causes enormous damage to the young plants and standing trees. According to Tesfaye et al. [59], saplings and medium-sized trees of Podocarpus falcatus were especially depleted in the heavily disturbed zone in Harenna forest. Our results indicate that a lower number of seedlings and saplings were observed very close to female trees $(4 \mathrm{~m}$ radius) than over longer distances. This may be because Podocarpus falcatus has a dense canopy that does not allow passing enough amounts of rain and light required for seedling establishment under the tree. It could also be because areas near a parent tree (the seed producing tree) become unfavorable for the survival of seedlings by soil pathogens. The Janzen-Connell hypothesis proposes that specialist natural enemies, such as pathogens, reduce survival rates of conspecific seeds and seedlings located close to reproductive adults [60]. Conversely, a larger proportion of $P$. falcatus seedlings were recorded under canopy shades, suggesting that $P$. falcatus can tolerate shading. Tesfaye and Teketay [46] reported that $79 \%$ of the P. falcatus seedling populations were found under the shade and $21 \%$ in open areas. Similar results were reported from other works on the species $[24,50,61]$.

\section{Conclusion and Recommendations}

Podocarpus falcatus is an extremely valuable tree species with a variety of economical and ecological services. Analysis of the population status indicates that the density of Podocarpus falcatus is 43 individuals $\mathrm{ha}^{-1}$ with a higher proportion of small-sized individuals in Dodola forest. The density distribution of $P$. falcatus by height and dbh classes shows an inverted J-shape pattern of population structure 
that reveals a good regeneration and recruitment status of the species in the forest. The sex category analysis of $P$. falcatus indicates the presence of a similar number of male and female trees in the forest and hence the total sex ratio of males to females did not deviate significantly from the theoretical sex ratio (1:1). The natural regeneration status of Podocarpus falcatus is relatively good owing to the presence of a larger number of individuals at the seedling stage. However, the lower number of individuals at the sapling stage requires appropriate conservation measures. A larger proportion of seedlings and saplings were recorded under canopy shades than in the open areas suggesting that $P$. falcatus is a shade-tolerant species. A smaller number of seedlings and saplings were observed within $4 \mathrm{~m}$ radius around female trees than over longer distances. Illegal felling of the preferred size of Podocarpus falcatus trees should be reduced and/or stopped by the combined efforts of the Adaba-Dodola Integrated Forest Management Project (IFMP) and the local administration. Further studies should be conducted to investigate why the regeneration status of Podocarpus falcatus is poor near the seed sources (female trees) as well as testing the Janzen-Connell hypothesis.

\section{Data Availability}

All the data for this study were collected from the field survey and are open to readers.

\section{Conflicts of Interest}

The authors declare that they have no conflicts of interest regarding the publication of this paper.

\section{Acknowledgments}

The authors are very grateful for the Graduate Program of Addis Ababa University for financial support and the local people of the study area for their hospitality and assistance in data collection.

\section{References}

[1] CBD (Convention on Biological Diversity), Convention on Biological Diversity, Secretariat of the Convention on Biological Diversity, Montreal, Canada, 1992.

[2] MEA (Millennium Ecosystem Assessment), Ecosystems and Human Well-Being: Synthesis. Millennium Ecosystem Assessment, Island Press, Washington, DC, USA, 2005.

[3] S. H. M. Butchart, M. Walpole, B. Collen et al., "Global biodiversity: indicators of recent declines," Science, vol. 328, no. 5982, pp. 1164-1168, 2010.

[4] SCBD (Secretariat of the Convention on Biological Diversity), Global Biodiversity Outlook 4, Secretariat of the Convention on Biological Diversity, Montréal, Canada, 2014.

[5] J. A. McNeely, R. A. Mittermeier, T. M. Brooks, F. Boltz, and N. Ash, The Wealth of Nature: Ecosystem Services, Biodiversity, and Human Well-Being, CEMEX, San Pedro Garza García, MX, USA, 2009.

[6] J. A. Sayer, C. S. Harcourt, and N. M. Collins, The Conservation Atlas of Tropical Forests of Africa, IUCN, Gland, Switzerland, 1992.
[7] Z. Woldu, S. Edward, A. Demissie, T. Bekele, and G. Haase, "Forests in the vegetation types of Ethiopia and their status in the geographical context," in Proceedings of the National Forest Genetic Resources Conservation Development Workshop, pp. 1-38, Addis Ababa, Ethiopia, 1999.

[8] EFAP (Ethiopian Forestry Action Program), The Challenge for Development, EFAP (Ethiopian Forestry Action Program), Addis Ababa, Ethiopia, 1994.

[9] D. Teketay, "Deforestation, wood famine, and environmental degradation in Ethiopia's highland ecosystems: urgent need for action," Northeast African Studies, vol. 8, no. 1, pp. 53-76, 2001.

[10] EBI (Ethiopian Biodiversity Institute), Ethiopia's 5th National Report to the Convention on Biological Diversity, EBI (Ethiopian Biodiversity Institute), Addis Ababa, Ethiopia, 2014.

[11] I. Hedberg, "The Ethiopian Flora Project-an overview," in Flora of Ethiopia and Eritrea, I. Hedberg, I. Friis, and E. Persson, Eds., vol. 8, Addis Ababa University, Addis Ababa, Ethiopia, 2009.

[12] E. Kelbessa and S. Demissew, "Diversity of vascular plant taxa of the flora of Ethiopia and Eritrea," Ethiopian Journal of Biological Sciences, vol. 13, pp. 37-45, 2014.

[13] M. Lemenih and D. Teketay, "Restoration of native forest flora in the degraded highlands of Ethiopia: constraints and opportunities," SINET: Ethiopian Journal of Science, vol. 27, no. 1, pp. 75-90, 2004.

[14] FAO, Global Forest Resources Assessment, Main Report, Food and Agriculture Organization of the United Nations, Rome, Italy, 2010.

[15] I. Friis, S. Demissew and P. Van Bruegel, Atlas of the Potential Vegetation of Ethiopia, Addis Ababa University Press and Shama Books, Addis Ababa, Ethiopia, 2011.

[16] I. Friis, Forest and Forest Trees of Northeast Tropical Africa; their Habitats And Distribution Pattern in Ethiopia, Djibouti and Somalia, Additional Series XV, Kew Bulletin. HMSO London, London, UK, 1992.

[17] L. Negash, Indigenous Trees of Ethiopia: Biology, Uses and Propagation Techniques, Printed by the SLU Reprocentralen, Umea, Sweden, 1995.

[18] L. Negash, "Review of research advances in some selected African trees with special reference to Ethiopia," Ethiopian Journal of Biological Sciences, vol. 1, no. 1, pp. 81-126, 2002.

[19] C. J. Geldenhuys, "Reproductive biology and population structures of Podocarpus falcatus and P. latifolius in Southern Cape forests," Botanical Journal of the Linnean Society, vol. 112, no. 1, pp. 59-74, 1993.

[20] N. Klapwijk, Podocarpus falcatus (Thunb.) R. B. ex. Mirb. National tree list No. 16, Pretoria National Botanical Garden, Pretoria, South Africa, 2002.

[21] D. Joker, Podocarpus falcatus (Thunb.) R. B. ex. Mirb. Seed Leaflet No. 75, Danida Forest Seed Center, Humlebaek, Denmark, 2003.

[22] S. Miehe and G. Miehe, Ericaceous Forests and Heath Lands in the Bale Mountains of South Ethiopia: Ecology and Man's Impact, Stiftung Walderhaltung in Africa, Hamburg, Germany, 1994.

[23] L. Negash and J. van Staden, "Vegetative propagation of the threatened East African yellowwood (Podocarpus falcatus)," South African Journal of Botany, vol. 69, no. 2, pp. 170-175, 2003.

[24] T. Yoshikura, "Population Status and Regeneration of Podocarpus falcatus in Magada Forest, Southern Ethiopia," M. Sc. thesis, University of Wales, Cardiff, UK, 2004. 
[25] F. Senbeta, T. Woldemariam, S. Demissew and M. Denich, "Floristic diversity and composition of Sheko forest, Southwest Ethiopia," Ethiopian Journal of Biological Science, vol. 6, no. 1, pp. 11-42, 2007.

[26] M. Argaw, D. Teketay and M. Olsson, "Soil seed flora, germination and regeneration pattern of woody species in an Acacia Woodland of the Rift Valley in Ethiopia," Journal of Arid Environments, vol. 43, no. 4, pp. 411-435, 1999.

[27] D. Muller-Dombois and H. Ellenberg, Aims and Methods of Vegetation Ecology, John Wiley and Sons, Hoboken, NJ, USA, 1974.

[28] M. Kent and P. Coker, Vegetation Description and Analysis: A Practical Approach, John Wiley and Sons, Hoboken, NJ, USA, 1992.

[29] R. R. Sokal and F. J. Rohlf, Biometry: The Principles and Practice of Statistics in Biological Research, Freeman, New York, NY, USA, 3rd edition, 1995.

[30] E. Lulekal, E. Kelbessa, T. Bekele and H. Yineger, "Plant species composition and structure of the Mana Angetu Moist Montane Forest, South-Eastern Ethiopia," Journal of East African Natural History, vol. 97, no. 2, pp. 165-185, 2008.

[31] G. Bekele, "Floristic composition and structure of the vegetation of Magada Forest, Borena zone, Oromia National Regional State," M. Sc. thesis, Addis Ababa University, Addis Ababa, Ethiopia, 2005.

[32] G. Fisaha, K. Hundera, and G. Dalle, "Woody plants' diversity, structural analysis and regeneration status of Wof Washa Natural Forest, North-East Ethiopia," African Journal of Ecology, vol. 51, no. 4, pp. 599-608, 2013.

[33] T. Soromessa and E. Kelbessa, "Interplay of regeneration, structure and uses of some woody species in Chilimo forest, Central Ethiopia," Science, Technology and Arts Research Journal, vol. 3, no. 1, pp. 90-100, 2014.

[34] E. Lulekal, "Plant diversity and ethnobotanical study of medicinal plants in Ankober District, North Shewa Zone of Amhara Region, Ethiopia" Ph.D. dissertation, Addis Ababa University, Addis Ababa, Ethiopia, 2014.

[35] T. Seta, "Forest structure, carbon stocks and leaf litter decomposition of two selected Afromontane forests in the Western Escarpment of Central Rift Valley and the Gibe Watershed, Ethiopia" Ph.D. dissertation, Addis Ababa University, Addis Ababa, Ethiopia, 2017.

[36] A. Assefa, "Vegetation ecology and land use/ land cover changes in selected Afromontane forests along Gibe-Omo watershed, Southwest Ethiopia" Ph.D. dissertation, Addis Ababa University, Addis Ababa, Ethiopia, 2017.

[37] F. Abdena, "Floristic composition and structure of vegetation of Chato Natural Forest in Horo Guduru Wollega zone, Oromia national regional state, West Ethiopia," M. Sc. thesis, Addis Ababa University, Addis Ababa, Ethiopia, 2010.

[38] R. J. Whittaker, K. J. Willis, and R. Field, "Climatic-energetic explanations of diversity: a macroscopic perspective," in Macroecology: Concepts and Consequences, T. M. Blackburn and K. J. Gaston, Eds., pp. 107-129, Cambridge University Press, Cambridge, UK, 2003.

[39] P. J. Grubb, J. R. Lloyd, T. D. Pennington, and T. C. Whitmore, "A comparison of Montane and lowland rain forest in Ecuador I. The forest structure, physiognomy and floristics," The Journal of Ecology, vol. 51, no. 3, pp. 567-601, 1963.

[40] J. W. Silvertown and J. L. Doust, Introduction to Plant Population Biology, Blackwell Science Ltd., London, UK, 1993.

[41] F. Senbeta and D. Teketay, "Diversity, community types and population structure of woody plants in Kimphee Forest, a virgin nature reserve in Southern Ethiopia," Ethiopian Journal of Biological Science, vol. 2, no. 2, pp. 169-187, 2003.

[42] K. Hundera, T. Bekele, and E. Kelbessa, "Floristic and phytogeographic synopsis of a dry Afromontane coniferous forest in the Bale Mountains, Ethiopia: implications to biodiversity conservation," SINET: Ethiopian Journal of Science, vol. 30, no. 1, pp. 1-12, 2007.

[43] M. B. Hailemariam and T. D. Temam, "The vegetation composition, structure and regeneration status of Gole Natural Forest, West Arsi Zone, Oromia Regional State, Ethiopia," Journal of Agricultural Science and Botany, vol. 2, no. 2, pp. 10-21, 2018.

[44] A. Tilahun, "Vegetation ecology and carbon stock of WofWasha Forest, North Shewa Zone, Amhara Region, Ethiopia," Ph. D. dissertation, Addis Ababa University, Addis Ababa, Ethiopia, 2018.

[45] N. Dejene, F. Kebede and M. Kebede, "Floristic composition, vegetation structure and regeneration status of Wabero forest, Oromia Regional State, Southeastern Ethiopia," International Journal of Biodiversity and Conservation, vol. 11, no. 9, pp. 272-279, 2019.

[46] G. Tesfaye and D. Teketay, "Distribution of Podocarpus falcatus along environmental gradients and its regeneration status in Harenna forest, Southeastern Ethiopia," Ethiopian Journal of Natural Resources, vol. 7, no. 1, pp. 111-129, 2005.

[47] M. Ahmed, M. Ashfaq, M. Amjad, and M. Saeed, "Vegetation structure and dynamics of Pinus gerardianaforests in Balouchistan, Pakistan," Journal of Vegetation Science, vol. 2, no. 1, pp. 119-124, 1991.

[48] Y. Y. Aye, S. Pampasit, C. Umponstira, K. Thanacharoenchanaphas and N. Sasaki, "Floristic composition, diversity and stand structure of tropical forests in Popa Mountain Park," Journal of Environmental Protection, vol. 05, no. 17, pp. 1588-1602, 2014.

[49] T. Bekele, Vegetation ecology of Remnant Afromontane forests of the central plateau of Shewa, Ethiopia, Opulus Press AB, Shewa, Ethiopia, 1993.

[50] D. Teketay, "Seedling populations and regeneration of woody species in dry Afromontane forests of Ethiopia," Forest Ecology and Management, vol. 98, no. 2, pp. 149-165, 1997.

[51] S. Senbeta, Biodiversity and eology of Afromontane rainforests with wild Coffea Arabica L. populations in Ethiopia, Ph.D. thesis, Center for Development Research, University of Bonn, Bonn, Germany, 2006.

[52] G. Tesfaye, D. Teketay, M. Fetene, and E. Beck, "Regeneration of seven indigenous tree species in a dry Afromontane forest, Southern Ethiopia," Flora-Morphology, Distribution, Functional Ecology of Plants, vol. 205, no. 2, pp. 135-143, 2010.

[53] D. Teketay and A. Granström, "Seed viability of Afromontane tree species in forest soils," Journal of Tropical Ecology, vol. 13, no. 1, pp. 81-95, 1997.

[54] D. Teketay, "Natural regeneration and management of Podocarpus falcatus (Thunb.) Mirb. in the Afromontane forests of Ethiopia," in Silviculture in the Tropics, S. Gunter, M. Weber, B. Stimm, and R. Mosandl, Eds., pp. 325-337, Tropical Forestry, Springer-Verlag, Berlin, Germany, 2011.

[55] U. Dhar, R. S. Rawal, and S. S. Samant, "Structural diversity and representativeness of forest vegetation in a protected area of Kumaun Himalaya, India: implications for conservation," Biodiversity and Conservation, vol. 6, no. 8, pp. 1045-1062, 1997.

[56] S. S. Samant, H. C. Joshi, S. C. Arya and S. Pant, "Studies on the structure, composition and changes of the vegetation in Nanda Devi Biosphere Reserve of West Himalaya," Final 
technical report, Ministry of Environment and Forests, New Delhi, India, 2002.

[57] A. Wassie, D. Teketay, and N. Powell, "Church forests in North Gonder administrative zone, Northern Ethiopia," Forests, Trees and Livelihoods, vol. 15, no. 4, pp. 349-373, 2005.

[58] A. Alelign, D. Teketay, Y. Yemshaw, and S. Edwards, "Diversity and status of regeneration of woody plants on the peninsula of Zegie, Northwestern Ethiopia," Tropical Ecology, vol. 48, no. 1, pp. 37-49, 2007.

[59] G. Tesfaye, D. Teketay, and M. Fetene, "Regeneration of fourteen tree species in Harenna forest, Southeastern Ethiopia," Flora-Morphology, Distribution, Functional Ecology of Plants, vol. 197, no. 6, pp. 461-474, 2002.

[60] L. S. Comita, S. A. Queenborough, S. J. Murphy et al., "Testing predictions of the Janzen-Connell hypothesis: a meta-analysis of experimental evidence for distance- and density-dependent seed and seedling survival," The Journal of Ecology, vol. 102, no. 4, pp. 845-856, 2014.

[61] M. Fetene and Y. Feleke, "Growth and photosynthesis of seedlings of four tree species from a dry tropical Afromontane forest," Journal of Tropical Ecology, vol. 17, no. 2, pp. 269-283, 2001. 